10.17951/g.2020.67.1.65-84

A N N A L E S

UNIVERSITATIS MARIAE CURIE-SKŁODOWSKA

LUBLIN - POLONIA

VOL. LXVII, 1

SECTIO G

2020

Wojewódzki Sąd Administracyjny w Lublinie

JAKUB POLANOWSKI

jpolanowski@wp.pl

ORCID: 0000-0003-3401-7479

\title{
Ograniczenie prawa własności nieruchomości w specustawach na przykładzie specustawy drogowej
}

Limitation of Real Estate's Ownership in Special Legislation on the Example of Road Special Legislation

\section{WPROWADZENIE}

W ujęciu chrześcijańskim pytanie o dobro (o wartość, jak zwykle mawiamy dzisiaj ${ }^{1}$ ) jest pytaniem skierowanym do tego, który jest źródłem wszelkiego dobra, czyli do Stwórcy. Tylko On może odpowiedzieć na nie, bo sam jest Dobrem. Jak wyjaśnia Jan Paweł II, odpowiedź ta została już udzielona w człowie$\mathrm{ku}$, w którego serce wpisano prawo naturalne - prawo będące światłem rozumu, dzięki któremu poznajemy, co należy czynić, gdyż jest dobrem, a czego unikać, gdyż dobrem nie jest ${ }^{2}$.

Owo „światło rozumu” ukierunkowuje człowieka na poznanie dobra i „pokochanie” go. Prowadzi zatem do specyficznego typu doświadczenia bytu jako dobra, doświadczenia określanego jako agatoniczne (gr. agathos 'dobro') bądź amabilne (łac. amare 'kochać'). W tym doświadczeniu metafizycznym człowiek odkrywa dobro jako ostateczną rację myślenia i działania bytu. W konsekwencji odkrycie to pozwala dostrzec całościowo cel i środki do tego celu prowadzące, określając zarazem - co niezwykle istotne, mając

1 Zob. H. Kiereś, Agatologia czy aksjologia?, [w:] Spór o dobro, red. A. Maryniarczyk, K. Stępień, P. Gondek, Lublin 2012, s. 107.

2 Jan Paweł II, Veritatis Splendor. Tekst i komentarze, Lublin 1999, s. 15 wraz z powołaną tam literaturą. 
na uwadze kwestie omawiane w niniejszej pracy - ich wzajemne uporządkowanie ${ }^{3}$.

Odnalezienie tej perspektywy ma doniosłe znaczenie we wszelkiej działalności poznawczej, ponieważ ukierunkowuje poznanie na te dobra, cenne wartości, które wymagają szerszej ochrony, a jednocześnie pozwala określić powody jej udzielenia. Tej ochrony należy poszukiwać przede wszystkim, gdy odnosimy się do człowieka jako dobra podstawowego, stanowiącego cel i kres prawa. Człowiekiem, a w konsekwencji również prawem dotykającym jego istoty, nie można manipulować, nie można więc czynić z nich środka do jakiegokolwiek celu, choćby najbardziej pożądanego społecznie. Granice wykorzystywania instytucji prawnych wyznacza przyrodzona i niezbywalna godność człowieka, stanowiąca zgodnie z art. 30 Konstytucji - źródło konstytucyjnych praw i wolności.

Trafnie wskazuje się w doktrynie, że godności ludzkiej nie można ograniczać, powołując się na prawa, nawet podstawowe, albowiem wyraża ona rdzeń tego dobra, jakim jest osobowość człowieka, jego poczucie wartości, jego podmiotowość prawna i prawnonaturalna pozycja w ramach ładu publicznego państwa. Z tego powodu godność człowieka może być samoistnym wzorcem kontroli zgodności z Konstytucją aktów normatywnych, które wprowadzają ograniczenia podstawowych praw i wolności, w tym ograniczenia prawa własności. Własność tkwi bowiem w naturze człowieka i naturze rzeczy, jest ,promieniowaniem” godności człowieka w rzeczach, co wynika także z tego, że poprzez pracę człowiek odciska na własności swoją istotę. Dlatego państwo nie może uzurpować sobie władzy do tego, by prawo własności sprowadzić do funkcji społecznej ${ }^{4}$.

Wcale nie jest łatwo dziś, w okresie afirmacji praw człowieka, pamiętając o stosunkowo niedalekiej przeszłości, kiedy prawa te były łamane być może równie powszechnie jak dziś ochoczo są akceptowane, określić, co jest rdzeniem prawa własności, niepodlegającym ograniczeniu, a co jest otoczką tego prawa, z natury rzeczy poddaną różnym ograniczeniom, wynikającym nie tylko z konieczności respektowania praw innych osób, lecz także z szeroko pojętego interesu publicznego. W ramach tak ujętego interesu publicznego należy umiejscowić potrzeby związane z procesem planowania i realizowania budowy obiektów o znaczeniu strategicznym, do których należą drogi, linie kolejowe, lotniska, sieci przesyłowe, inwestycje służące zabezpieczeniu obronności i bezpieczeństwa publicznego, jak obiekty przeciwpowodziowe i wiele innych tego typu. Wiadome jest, że realiza-

3 A. Maryniarczyk, Dobro bytu, [w:] S. Thomae Aquinatis. Quaestiones disputatae de bono, de appetitu boni et voluntate - Dysputy problemowe o dobru, o pożądaniu dobra i o woli, red. A. Maryniarczyk, Lublin 2003, s. 223 wraz z powołaną tam literaturą.

4 M. Zdyb, Konstytucyjne podstawy administracyjnoprawnych ograniczeń prawa wtasności jako podstawowego prawa rzeczowego (i ograniczonych praw rzeczowych), [w:] System Prawa Administracyjnego, t. 7: Prawo administracyjne materialne, red. R. Hauser, A. Wróbel, Z. Niewiadomski, Warszawa 2017, s. 594 i n. wraz z powołaną tam literaturą. 
cja takich inwestycji infrastrukturalnych traktowana jest w sposób priorytetowy przez władze publiczne w Polsce, co wynika zarówno z wymagań innowacyjnej gospodarki, jak i z zaniedbań istniejących w tym obszarze inwestycji publicznych. Źródeł tych zaniedbań jest wiele i są one bardzo zróżnicowane. Widać to dobrze na przykładzie gęstości pokrycia sieci linii kolejowych na obszarze dawnego zaboru rosyjskiego oraz na obszarze kraju. Pozytywnie zatem należy ocenić dbałość w podejmowaniu przez władze publiczne działań służących modernizacji istniejących oraz budowie nowych, odpowiadających wymaganiom nowoczesnej gospodarki, obiektów infrastrukturalnych. Potrzeba ta dotyczy w równej mierze inwestycji o znaczeniu ogólnokrajowym oraz inwestycji regionalnych i lokalnych.

\section{KWESTIA TZW. SPECUSTAW}

Niewątpliwie wskazane wyżej specyficzne uwarunkowania krajowe, związane z niedoinwestowaniem całych sektorów budownictwa, logistyki, energetyki i innych tego typu zamierzeń inwestycyjnych, wymagają trafnego znalezienia rozwiązań prawnych ułatwiających naprawę tych sektorów gospodarki. Dodatkowo wciąż istotny problem ubóstwa, znacznego rozdrobnienia własności nieruchomości, połączonego niekiedy z brakiem prawnego uregulowania kwestii własnościowych, a czasem także prowadzenie sporów pieniaczych sprawiają, że prowadzenie inwestycji infrastrukturalnych, w tym zwłaszcza związanych z koniecznością budowy sieci dróg szybkiego ruchu, napotykało od wielu lat istotne przeszkody. Takie uwarunkowania zachęciły ustawodawcę do poszukiwania szczególnego, specyficznego unormowania omawianej problematyki. Wyrazem tego dążenia było wprowadzenie przepisów tzw. specustaw, tj. ustaw o charakterze specjalnym, niekiedy wręcz z założenia doraźnym, które charakteryzują się przyjęciem rozwiązań nadzwyczajnych, służących osiągnięciu określonego celu, najczęściej realizacji konkretnej inwestycji bądź rodzaju inwestycji, o szczególnie istotnym znaczeniu z punktu widzenia interesu publicznego.

Najstarszym w zasadzie tego typu aktem normatywnym ${ }^{5}$ jest ustawa $\mathrm{z}$ dnia 10 kwietnia 2003 r. o szczególnych zasadach przygotowania i realizacji inwestycji w zakresie dróg publicznych ${ }^{6}$. Niewątpliwie skuteczność zastosowania instytucji prawnych przewidzianych $w$ tej ostatniej ustawie dla realizacji inwestycji drogowych przesądziła w znacznej mierze o uchwaleniu kolejnych aktów normatywnych, których rozwiązania oparto na modelu wypracowanym w przepisach tej

5 Wcześniejsza jest ustawa z dnia 28 marca 2003 r. o transporcie kolejowym (Dz.U. 2019, poz. 710), która jednak dopiero od zmiany dokonanej ustawą z dnia 16 grudnia 2005 r. o zmianie ustawy o transporcie kolejowym oraz o zmianie innych ustaw (Dz.U. 2006, nr 12, poz. 63), na mocy której wprowadzono szczególne przepisy dotyczące budowy i przebudowy linii kolejowych, może być traktowana jako ustawa specjalna w zakresie inwestycyjnym.

6 Dz.U. 2018, poz. 1474 ze zm., dalej także jako: ustawa bądź specustawa drogowa. 
ustawy, wprowadzających ułatwienia w realizacji określonych inwestycji. Do aktów tych, nazywanych nie tylko potocznie, lecz także w doktrynie i orzecznictwie sądów administracyjnych „specustawami”, zaliczyć należy m.in. ustawy: z dnia 7 września 2007 r. o przygotowaniu finałowego turnieju Mistrzostw Europy w Piłce Nożnej UEFA EURO 20127 ; z dnia 12 lutego 2009 r. o szczególnych zasadach przygotowania i realizacji inwestycji w zakresie lotnisk użytku publicznego ${ }^{8}$; z dnia 24 kwietnia 2009 r. o inwestycjach w zakresie terminalu regazyfikacyjnego skroplonego gazu ziemnego w Świnoujściu'; z dnia 7 maja 2010 r. o wspieraniu rozwoju usług i sieci telekomunikacyjnych ${ }^{10}$; z dnia 24 czerwca 2010 r. o szczególnych rozwiązaniach związanych z usuwaniem skutków powodzi z 2010 r. $^{11}$; z dnia 8 lipca 2010 r. o szczególnych zasadach przygotowania do realizacji inwestycji w zakresie budowli przeciwpowodziowych ${ }^{12}$; z dnia 29 czerwca $2011 \mathrm{r}$. o przygotowaniu i realizacji inwestycji w zakresie obiektów energetyki jądrowej oraz inwestycji towarzyszących ${ }^{13}$; z dnia 16 września 2011 r. o szczególnych rozwiązaniach związanych z usuwaniem skutków powodzi ${ }^{14}$; z dnia 24 lipca 2015 r. o przygotowaniu i realizacji strategicznych inwestycji w zakresie sieci przesyłowych ${ }^{15}$; z dnia 24 lutego 2017 r. o inwestycjach w zakresie budowy drogi wodnej łączącej Zalew Wiślany z Zatoką Gdańską ${ }^{16}$; z dnia 7 kwietnia 2017 r. o inwestycjach w zakresie budowy lub przebudowy toru wodnego Świnoujście-Szczecin do głębokości 12,5 metra ${ }^{17}$; z dnia 10 maja 2018 r. o Centralnym Porcie Komunikacyjnym $^{18}$; z dnia 10 maja 2018 r. o wspieraniu nowych inwestycji ${ }^{19}$; z dnia 5 lipca 2018 r. o ułatwieniach w przygotowaniu i realizacji inwestycji mieszkaniowych oraz inwestycji towarzyszących ${ }^{20}$; z dnia 22 lutego 2019 r. o przygotowaniu i realizacji strategicznych inwestycji w sektorze naftowym ${ }^{21}$.

W prawie administracyjnym jest oczywiście również wiele innych aktów normatywnych tego typu, niedotyczących procesu inwestycyjno-budowlanego. Podejmowanie tych aktów służy osiągnięciu doraźnego celu ekonomicznego,

\footnotetext{
Dz.U. 2017, poz. 1372.

Dz.U. 2018, poz. 1380 ze zm.

Dz.U. 2017, poz. 2302 ze zm.

Dz.U. 2017, poz. 2062 ze zm.

Dz.U. nr 123, poz. 835 ze zm.

Dz.U. 2019, poz. 933 ze zm.

Dz.U. 2018, poz. 1537.

Dz.U. 2018, poz. 1473 ze zm.

Dz.U. 2018, poz. 404 ze zm.

Dz.U. 2019, poz. 1073.

Dz.U. 2017, poz. 990.

Dz.U. 2018, poz. 1089 ze zm.

Dz.U. 2018, poz. 1162 ze zm.

Dz.U. 2018, poz. 1496 ze zm.

Dz.U. 2019, poz. 630 ze zm.
} 
podatkowego, organizacyjnego czy politycznego, przy pomocy skróconej procedury i nadmiernie uproszczonego schematu działania organów administracji, co z uwagi na naruszenia podstawowych zasad prawa administracyjnego i zasad ustrojowych, a także z uwagi na jakość tworzonego prawa stanowi niezwykle problematyczne zagadnienie ${ }^{22}$.

Źródeł takiego postępowania ustawodawcy jest wiele. Wśród nich wymienić należy, oprócz wskazanych wyżej uwarunkowań, aksjologiczne problemy ładu prawnego, które wynikają zwłaszcza z wyzwolenia prawa administracyjnego od wartości, w tym deprecjacji moralności publicznej i nihilizmu aksjologicznego oraz gloryfikacji procedur kosztem prawa materialnego, prowadzących do utraty poczucia bezpieczeństwa prawnego ${ }^{23}$.

Nie jest celem niniejszej pracy szukanie rozstrzygnięcia, czy przyjęcie takiego sposobu uregulowania niektórych sfer działalności inwestycyjnej finalnie ocenić należy jako trafne. Proces przyjmowania - w tak szerokim zakresie - rozwiązań prowizorycznych i tymczasowych, jakie cechują regulacje specjalnych ustaw inwestycyjnych, świadczy jednak z całą pewnością o bezsilności państwa i jednostek samorządu terytorialnego wobec stosowania ogólnych rozwiązań wynikających z przepisów prawa budowlanego i prawa zagospodarowania przestrzennego. Podmioty te nie są bowiem w stanie, przy wykorzystaniu modelowych rozwiązań materialnych i procesowych, w sposób efektywny przygotowywać i prowadzić inwestycje infrastrukturalne. Osiągnięcie zaś takiego celu ułatwia uproszczenie przepisów postępowania, połączenie różnych postępowań w jedno, ograniczenie praw stron postępowania, a co za tym idzie skrócenie procesu wstępnego realizacji inwestycji. W efekcie jednak to, co powinno być traktowane jako wyjątek, stało się zasadą ${ }^{24}$.

\section{CHARAKTERYSTYKA ROZWIĄZAŃ SPECUSTAWY DROGOWEJ}

Rozwiązania zawarte w ustawie o inwestycjach drogowych ulegały na przestrzeni jej obowiązywania dość istotnym modyfikacjom. Co najbardziej istotne, o ile w początkowym okresie ustawa regulowała jedynie zasady i warunki przygotowania inwestycji w zakresie dróg publicznych o szczególnym znaczeniu z punktu widzenia interesu publicznego - dróg krajowych, o tyle w wyniku nowelizacji

22 Zob. J. Zimmermann, Prawo administracyjne, Warszawa 2014, s. 64.

${ }^{23}$ Szerzej zob. M. Zdyb, Dylematy ładu prawnego w kontekście inflacji i niektórych innych niedoskonałości prawa administracyjnego, [w:] Prawo administracyjne dziś i jutro, red. J. Jagielski, M. Wierzbowski, Warszawa 2018, s. 42 i n.

${ }^{24}$ Zob. zamiast wielu: M. Kotulski, Problemy w ksztattowaniu przestrzeni w procesie planowania i zagospodarowania przestrzennego, [w:] Przestrzeń i nieruchomości jako przedmiot prawa administracyjnego. Publiczne prawo rzeczowe, red. I. Niżnik-Dobosz, Warszawa 2012, s. 40-41. 
dokonanej z dniem 16 grudnia 2006 r. ${ }^{25}$ zakresem przedmiotowym ustawy objęto wszystkie drogi publiczne w Polsce. Tym samym ustawa utraciła swój cząstkowy charakter, a jej unormowania stały się swego rodzaju drogowym „kodeksem” budowlanym. Rozwiązanie to, być może zrozumiałe, wziąwszy pod uwagę potrzebę zintensyfikowania budowy dróg publicznych, zrodziło jednak wiele wątpliwości dotyczących zastosowanego mechanizmu wyważenia interesu publicznego i interesu prywatnego. Do kwestii tych wrócę w dalszej części pracy.

Przepisy omawianej ustawy zawierają szereg odrębności w stosunku do przepisów procesowych i materialnych prawa administracyjnego. Najistotniejsze z nich dotyczą znacznego uproszczenia i skrócenia postępowania kosztem rezygnacji z niektórych uprawnień procesowych pozostałych (poza wnioskodawcą) stron, ograniczeń w zakresie uprawnień orzeczniczych organów administracji i sądów administracyjnych, a także wyłączenia niektórych szczegółowych, restrykcyjnych dla wnioskodawcy obowiązków materialnych. Zawiadomienie o wszczęciu postępowania w sprawie wydania decyzji o zezwoleniu na realizację inwestycji drogowej doręcza się właścicielom nieruchomości objętych wnioskiem o wydanie tej decyzji nie na adres ich zamieszkania, lecz na adres wskazany w ewidencji gruntów i budynków (art. 11d ust. 5 ustawy). Decyzję o zezwoleniu na realizację inwestycji drogowej doręcza się jedynie podmiotowi publicznemu, będącemu wnioskodawcą, a pozostałym stronom - w tym dotychczasowym właścicielom nieruchomości - w trybie obwieszczenia, o jakim mowa w art. 49 ustawy z dnia 14 czerwca $1960 \mathrm{r}$ - Kodeks postępowania administracyjnego ${ }^{26}$, z tym że organ dodatkowo przesyła zawiadomienie o wydaniu decyzji tym właścicielom, lecz tylko na adres wskazany w ewidencji gruntów i budynków (art. 11f ust. 3). Analogiczne zasady zawiadamiania o wszczęciu postępowania i doręczeniu aktów w nim wydanych dotyczą postępowań nadzwyczajnych (art. 11f ust. 7). W postępowaniu nadzwyczajnym dotyczącym decyzji realizacyjnej, prowadzonym w trybie art. 155 k.p.a., jedyną stroną, która wyraża zgodę na jej zmianę, jest podmiot publiczny, będący wnioskodawcą realizacji inwestycji drogowej (art. 11f ust. 8). Ponadto, co - z uwagi na wspomniane wyżej specyficzne uwarunkowania własnościowe oraz wieloletnie zaniedbania wynikające $\mathrm{z}$ braku świadomości prawnej - ma niemałe praktyczne znaczenie, ustawa drogowa dopuszcza prowadzenie postępowania zmierzającego do wydania decyzji o zezwoleniu na realizację inwestycji drogowej nawet wtedy, gdy przedmiotem tego postępowania są nieruchomości o nieuregulowanym stanie prawnym oraz w sytuacji, gdy właściciel lub użytkownik wieczysty nieruchomości nie żyją, a ich spadkobiercy nie

${ }^{25}$ Na mocy przepisów ustawy z dnia 18 października 2006 r. o zmianie ustawy o szczególnych zasadach przygotowania i realizacji inwestycji w zakresie dróg krajowych oraz o zmianie niektórych innych ustaw (Dz.U. nr 220, poz. 1601 ze zm.).

26 Dz.U. 2018, poz. 2096 ze zm., dalej: k.p.a. 
wykazali prawa do spadku. W takim wypadku organ odstępuje obligatoryjnie od przesyłania zawiadomienia o wydaniu decyzji na wskazany w ewidencji adres wskazanego tam poprzedniego właściciela (art. 11f ust. 5). W odniesieniu zaś do nieruchomości o nieuregulowanym stanie prawnym zawiadomienie o wszczęciu postępowania wysyła się jedynie wnioskodawcy (art. 11d ust. 7). Poza tym, jak przyjmuje się $\mathrm{w}$ orzecznictwie, na gruncie przepisów ustawy nie ma podstaw do wyłączenia odpowiednio: prezydenta miasta na prawach powiatu (w sprawach decyzji realizacyjnej dla drogi gminnej i powiatowej) i starosty (w sprawach decyzji realizacyjnej dla drogi powiatowej) ${ }^{27}$. Takie rozwiązanie, jak trafnie wskazuje się w doktrynie, ma istotne znaczenie, zważywszy, że właśnie podmiot wnioskujący o wydanie decyzji realizacyjnej ma największy wpływ na planowany przebieg drogi, a w konsekwencji na to, jakie nieruchomości zostaną wywłaszczone w związ$\mathrm{ku} \mathrm{z}$ budową drogi ${ }^{28}$. Zarazem przepisy ustawy wprowadzają niezwykle szeroko możliwość nadania decyzji realizacyjnej wydanej w pierwszej instancji rygoru natychmiastowej wykonalności (art. 17 ust. 1 ustawy), co - jak będzie niżej wskazane - ma istotne znaczenie z punktu widzenia granic ochrony interesu prawnego właścicieli nieruchomości objętych inwestycją drogową. Wreszcie w postępowaniach przed organem odwoławczym oraz przed sądem administracyjnym (które są przyspieszone i nie mogą trwać dłużej niż odpowiednio 30 dni oraz 2 miesiące) nie można uchylić decyzji w całości ani stwierdzić jej nieważności, gdy wadą dotknięta jest tylko część decyzji dotycząca odcinka drogi, nieruchomości, działki (art. 11g ust. 2 i 3). Decyzji tej sąd administracyjny nie może w ogóle wyeliminować z obrotu prawnego, gdy nadano jej rygor natychmiastowej wykonalności, a skarga wpłynęła do sądu po upływie 14 dni od dnia rozpoczęcia budowy drogi. Uwzględniając skargę, sąd może wówczas jedynie stwierdzić, że decyzja narusza prawo z przyczyn wskazanych $\mathrm{w}$ art. 145 lub 156 k.p.a. Te same ograniczenia dotyczą rozstrzygnięć podejmowanych w nadzwyczajnych trybach postępowania (art. 31 ust. 1 i 2 ).

Należy także dodać, że decyzja o zezwoleniu na realizację inwestycji drogowej jest aktem szczególnym, gdyż łączy w sobie elementy władcze różnego typu decyzji administracyjnych, podejmowanych na podstawie przepisów innych ustaw, m.in. decyzji o lokalizacji inwestycji celu publicznego, pozwoleniu na budowę, wywłaszczeniu nieruchomości, podziale nieruchomości, ograniczeniu sposobu korzystania z nieruchomości. Specyfika uregulowań przyjętych w ustawie ujawnia się niekiedy dopiero po przeanalizowaniu przepisów poszczególnych

27 Zamiast wielu zob. wyrok NSA z dnia 27 września 2016 r., II OSK 1887/19, LEX nr 2167520.

28 J. Parchomiuk, Uproszczone procedury realizacji publicznych inwestycji infrastrukturalnych a ochrona praw jednostki, [w:] Przestrzeń i nieruchomości jako przedmiot prawa administracyjnego..., s. 346. 
ustaw materialnego prawa administracyjnego, które zupełnie inaczej, dużo bardziej restrykcyjnie dla wnioskodawcy, regulują warunki udzielanych zgód na planowane przez niego działania. Charakterystyczna dla specustawy drogowej skąpość regulacji, która to ustawa wyłącza zarazem stosowanie przepisów ogólnych, wyraża się np. w tym, że zawarte w decyzji realizacyjnej zezwolenie na usunięcie drzew i krzewów nie jest powiązane $\mathrm{z}$ nałożeniem obowiązku wykonania nasadzeń kompensacyjnych, co ma miejsce w odniesieniu do „Zwykłego” wnioskodawcy, na podstawie przepisów ustawy z dnia 16 kwietnia 2004 r. o ochronie przyrody ${ }^{29}$. Odnoszący się do tej kwestii przepis art. 21 ust. 2 specustawy drogowej przewiduje wprost wyłączenie przepisów o ochronie przyrody w zakresie obowiązku uzyskiwania zezwoleń na ich usunięcie oraz opłat z tym związanych, poza wyjątkowymi sytuacjami, gdy drzewa i krzewy usuwane są z nieruchomości wpisanej do rejestru zabytków.

Na marginesie wskazać należy, że ułatwienia procesowe i materialne dotyczące inwestycji realizowanych na podstawie przepisów omawianej ustawy wynikają także z przepisów innych ustaw. W szczególności uregulowania nowej ustawy Prawo wodne ${ }^{30}$, w świetle jej art. 545, nie mają zastosowania nie tylko do spraw z zakresu prawa wodnego, prawa budowlanego, ocen oddziaływania przedsięwzięcia na środowisko itp., w których w dniu wejścia w życie tej ustawy postępowanie było wszczęte i niezakończone decyzją ostateczną, lecz również do wszystkich spraw - także tych, w których postępowanie wszczęto pod rządami tej ustawy - rozpoznawanych w oparciu o przepisy kilkunastu specustaw, w tym ustawy drogowej.

\section{OCHRONA INTERESU PUBLICZNEGO W SPECUSTAWIE DROGOWEJ}

Oczywiste wydaje się dziś stwierdzenie, że na gruncie prawa administracyjnego nie ma miejsca dla sztywnie pojmowanego prymatu interesu publicznego nad interesem indywidualnym ${ }^{31}$. Trudno wszakże oprzeć się wrażeniu, że przyjęta w omawianej ustawie koncepcja wyważania tych interesów prowadzi jednak do takiego właśnie, sprzecznego z duchem art. 2 Konstytucji, rozwiązania. Rozważania poniższe dotyczą tylko jednego aspektu tego zagadnienia, choć niewątpliwie zakres przyjętych w tej ustawie rozwiązań prowadzących mniej lub bardziej bez-

29 Dz.U. 2018, poz. 1614.

${ }^{30}$ Ustawa z dnia 20 lipca 2017 r. - Prawo wodne (Dz.U. 2018, poz. 2268 ze zm.).

${ }^{31} \mathrm{Na}$ ten temat zob. zamiast wielu: E. Komierzyńska, M. Zdyb, Klauzula interesu publicznego w działaniach administracji publicznej, „Annales UMCS sectio G (Ius)” 2016, nr 2, DOI: http:// dx.doi.org/10.17951/g.2016.63.2.161, passim. Z orzecznictwa zob. np. wyrok NSA z dnia 25 lutego 2014 r., II GSK 1924/12, LEX nr 1495127, dotyczący sprawy rozstrzygniętej na gruncie innych przepisów materialnoprawnych, ale wskazujący przykład argumentacji pozwalającej na wyważenie obu interesów. 
pośrednio do ograniczenia praw właścicieli nieruchomości, objętych projektowanym przebiegiem drogi publicznej, jest nadzwyczaj szeroki.

Zauważyć należy, co podniesiono już wyżej, że wskazana we wniosku o wydanie decyzji realizacyjnej lokalizacja planowanej drogi przesądza o tym, jakie nieruchomości zostaną w związku z tą inwestycją wywłaszczone. Kwestia ta ma zatem niezwykle istotne znaczenie z punktu widzenia ochrony prawa własności. $\mathrm{Z}$ tego też powodu stała się przedmiotem wniosku Rzecznika Praw Obywatelskich o podjęcie przez skład poszerzony Naczelnego Sądu Administracyjnego uchwały abstrakcyjnej. Rzecznik domagał się w tym trybie wyjaśnienia, czy przesłanki niezbędności i celowości realizacji inwestycji publicznej w kształcie przedstawionym przez wnioskodawcę, będącego zarządcą drogi publicznej, mieszczą się w zakresie oceny przez organ w kontekście dopuszczalności wywłaszczenia w rozumieniu art. 21 ust. 2 Konstytucji RP ${ }^{32}$ i art. 112 ust. 3 ustawy z dnia 21 sierpnia 1997 r. o gospodarce nieruchomościami ${ }^{33}$. Postanowieniem z dnia 17 grudnia 2014 r. ${ }^{34}$ NSA odmówił podjęcia uchwały w tej kwestii, uznając, że sposób sformułowania we wniosku pytania uniemożliwia, w myśl art. $264 \S 2 \mathrm{w}$ zw. z art. 15 $\S 1$ pkt 2 ustawy z dnia 30 sierpnia 2002 r. - Prawo o postępowaniu przed sądami administracyjnymi ${ }^{35}$, podjęcie tego orzeczenia. Jednocześnie jednak NSA zawarł krótki wywód wskazujący w istocie, jakie stanowisko zająłby w tej sprawie, gdyby wniosek RPO został skonstruowany poprawnie. Mianowicie stwierdził, że nie dostrzega podstaw, by kwestionować przyjęty przez inwestora przebieg drogi. Wskazał przy tym m.in.: „Jeżeli przyjmujemy, że przebieg drogi jest wyznaczony w sposób racjonalny przez grono specjalistów z zakresu transportu, geologii, ochrony środowiska, musimy przyjąć nieuchronność zajęcia ściśle oznaczonych gruntów pod budowę drogi”. Uzasadniając krótko ten pogląd, NSA przywołał także trzy argumenty, którymi posłużył się Trybunał Konstytucyjny w wyroku z dnia 16 października $2012 \mathrm{r}^{36}{ }^{36}$, dotyczące tego, że budowa bezpiecznych dróg w Polsce leży w interesie wszystkich, w tym wywłaszczonych, jak również że uproszczona procedura wywłaszczenia z mocy prawa, stosowana podczas realizacji inwestycji liniowych, jest metodą skuteczną oraz że lokalizacja drogi niejako narzuca listę nieruchomości, które muszą być zajęte, a zatem wywłaszczone.

Nie lekceważąc praktycznego znaczenia powyższych argumentów, zakładających konieczność takiej wykładni przepisów specustawy drogowej, która za-

32 Konstytucja Rzeczypospolitej Polskiej z dnia 2 kwietnia 1997 r. (Dz.U. 1997, nr 78, poz. 483 ze zm.).

${ }^{33}$ Dz.U. 2014, poz. 518 ze zm., obecnie: Dz.U. 2018, poz. 2204 ze zm., dalej: u.g.n.

34 II OPS 2/14, LEX nr 1566894.

${ }^{35}$ Dz.U. 2018, poz. 1302 ze zm., dalej: p.p.s.a.

${ }^{36}$ K 4/10, OTK-A 2012, nr 9, poz. 106. Do wyroku tego sędzia Trybunału Konstytucyjnego W. Hermeliński zgłosił zdanie odrębne, zwracając uwagę m.in. na wątpliwości dotyczące zachowania należytego standardu ochrony prawa własności w kontekście ograniczenia prawa do sądu. 
gwarantuje skuteczną realizację jej celu zasadniczego, jakim jest przyspieszenie budowy dróg publicznych w Polsce, należy zwrócić uwagę na wątpliwości, które nasuwa takie stanowisko, utrwalone obecnie w orzecznictwie sądów administracyjnych.

Podkreślenia wymaga, w opozycji do wyrażonego wyżej poglądu, że zawarte we wniosku rozstrzygnięcie zarządcy drogi publicznej dotyczące wytyczenia drogi cechuje się pewną swobodą. Pamiętać trzeba, że w przeciwieństwie do inwestycji niemających charakteru publicznego wnioskodawca nie ma obowiązku wykazywania prawa do dysponowania nieruchomością na cele budowlane. $Z$ istoty tego procesu inwestycyjnego wynika, że z uwagi na publiczny cel planowanej inwestycji kwestie własnościowe nie mogą mieć przesądzającego znaczenia o dopuszczalności zaplanowanego przez inwestora zamierzenia budowlanego. Nie można jednak zapominać, że przebieg takiej inwestycji liniowej, właśnie z uwagi na ochronę konstytucyjnego prawa własności, powinien być wyznaczony nie tylko zgodnie z planem miejscowym bądź decyzją o lokalizacji inwestycji celu publicznego, lecz także w sposób najmniej uciążliwy dla właściciela nieruchomości, niebędącego wnioskodawcą. Taka zasada została wyrażona w orzecznictwie sądów administracyjnych w odniesieniu do spraw dotyczących mniej dotkliwej ingerencji w sposób wykonywania prawa własności nieruchomości, przewidzianej obecnie w przepisach art. 124 i n. u.g.n. Wyjaśniając to stanowisko, wskazuje się, że w takich sprawach uzasadniony interes właściciela nieruchomości wymaga, aby przebieg planowanej inwestycji był dla jego nieruchomości jak najmniej uciążliwy, a zakres ingerencji inwestora $\mathrm{w}$ prawa właściciela nieruchomości sprowadzony do niezbędnego minimum. Organ wydający decyzję na podstawie art. 124 ust. 1 u.g.n. nie zawsze może się więc ograniczyć do badania jedynie tego, czy zakładanie i prawidłowe przeprowadzenie na nieruchomości określonych ciągów drenażowych, przewodów i urządzeń jest inwestycją spełniającą przesłanki inwestycji celu publicznego oraz czy planowane ograniczenie sposobu korzystania z nieruchomości następuje zgodnie z planem miejscowym (decyzją o ustaleniu lokalizacji inwestycji celu publicznego). Obowiązany jest również, na podstawie art. 7 k.p.a., wyważyć interes indywidualny i interes społeczny w odniesieniu do określonego we wniosku ograniczenia sposobu korzystania z nieruchomości związanego z inwestycją ${ }^{37}$. Tym bardziej więc należałoby domagać się zachowania takiego standardu ochrony własności w przypadku całkowitego odebrania tego prawa, do jakiego dochodzi z mocy prawa na skutek zyskania ostateczności przez decyzję realizacyjną (art. 12 ust. 4 ustawy). Nie ulega przecież wątpliwości, że zakładanie i przeprowadzanie na nieruchomości ciągów drenażowych, przewodów i urządzeń służących do przesyłania lub dystrybucji płynów, pary, gazów i energii elektrycznej oraz urządzeń łączności publicznej i sygnalizacji,

37 Zob. np. wyrok NSA z dnia 7 lipca 2017 r., I OSK 2668/15, LEX nr 2347631. 
wraz z niezbędną infrastrukturą, także stanowi priorytetowe zadanie publiczne, którego realizacja jest w interesie wszystkich członków społeczeństwa. Również w tym zakresie pożyteczna byłaby regulacja „skuteczna”, a przy tym zasadniczo w analogiczny sposób przebiega w przypadku takich inwestycji ustalanie ich przebiegu. Trudno więc wyjaśnić taką dysproporcję w zakresie udzielanej przez państwo ochrony właścicielom nieruchomości w opisanych wyżej kategoriach spraw administracyjnych, odwołując się do argumentów przywołanych wyżej. Gorzko można w tym miejscu zauważyć, że chyba sam ustawodawca dostrzegł „słabość” opisanego unormowania, skoro również dla usprawnienia realizacji niektórych inwestycji w zakresie sieci przesyłowych ustanowił regulację szczególną we wspomnianej już ustawie z dnia 24 lipca 2015 r. o przygotowaniu i realizacji strategicznych inwestycji w zakresie sieci przesyłowych.

Trzeba mieć przy tym na uwadze, że w przypadku podjęcia decyzji o zezwoleniu na realizację inwestycji drogowej przepisy prawa nie wskazują lokalizacji tej inwestycji. Pośrednio jedynie wysnuć z nich można, gdzie droga znaleźć się nie może, co wynikać może z wymogów przyrodniczych, krajobrazowych, związanych z obronnością czy bezpieczeństwem państwa itp. Nie ulega wątpliwości, że w przypadku wydania decyzji o sposobie ograniczenia prawa własności nieruchomości w celu przeprowadzenia przez nią sieci przesyłowych bądź innych tego rodzaju urządzeń infrastruktury technicznej organ ma obowiązek zweryfikować, czy przebieg tych urządzeń jest zgodny z decyzją o lokalizacji celu publicznego bądź miejscowym planem zagospodarowania przestrzennego. Zarazem jednak twierdzi się w orzecznictwie sądowym, że wymóg zgodności z zapisami planu miejscowego nie może zostać uznany za spełniony w sytuacji, gdy określony przebieg inwestycji wynika jedynie z ogólnych zapisów planu miejscowego, np. wskazujących, że sieci infrastruktury technicznej mogą być zlokalizowane w liniach rozgraniczających dróg publicznych ${ }^{38}$. Argumentem za przyjęciem tego stanowiska jest przede wszystkim wzgląd na zachowanie konstytucyjnego standardu wywłaszczenia na cel określony $\mathrm{w}$ ustawie oraz $\mathrm{z}$ zachowaniem zasady proporcjonalności. Sądy wskazują bowiem, że wymóg zachowania zgodności ograniczenia wynikającego z decyzji o czasowym zajęciu nieruchomości z planem miejscowym albo z decyzją o ustaleniu lokalizacji inwestycji celu publicznego odnosi się przede wszystkim do obszaru nieruchomości, który został objęty przeznaczeniem pod budowę publicznych urządzeń infrastruktury technicznej lub na którym została ustalona lokalizacja tego typu inwestycji. Tylko wobec takiej

${ }^{38}$ Pogląd ten przeważa obecnie w orzecznictwie NSA. Zob. np. wyroki NSA z dnia: 2 lutego 2017 r., I OSK 1036/15, LEX nr 2253603; 2 marca 2017 r., I OSK 1196/15, LEX nr 2348986; 21 marca 2017 r., I OSK 1704/15, LEX nr 2289926. W orzecznictwie i doktrynie wyrażono jednak również odmienne stanowisko. Zob. G. Matusik, [w:] G. Bieniek, M. Gdesz, S. Kalus, G. Matusik, E. Mzyk, Ustawa o gospodarce nieruchomościami. Komentarz, Warszawa 2012, s. 719. Zob. także zamiast wielu: wyrok NSA z dnia 23 października 2014 r., I OSK 537/13, LEX nr 1591039. 
części obszaru nieruchomości może być wydana decyzja o zezwoleniu na czasowe jej zajęcie, który jest niezbędny dla posadowienia na nim tych urządzeń oraz wykonania związanych z tym posadowieniem robót budowlanych. Trafnie podkreśla się przy tym specyfikę postępowania dotyczącego czasowego zajęcia nieruchomości, wskazując, że ograniczenie sposobu korzystania z nieruchomości na podstawie art. 124 ust. 1 u.g.n., zawartego w rozdziale „Wywłaszczanie nieruchomości”, kwalifikować należy jako jeden ze sposobów wywłaszczenia. Dlatego też hipotezy tej normy nie można interpretować rozszerzająco, zwłaszcza że w przeciwieństwie do przymusowego ustanowienia służebności przesyłu w postępowaniu cywilnym - art. 124 ust. 1 u.g.n. nie przewiduje możności przyznania właścicielowi nieruchomości wynagrodzenia za korzystanie z nieruchomości. Świadczenia przysługujące właścicielowi nieruchomości na podstawie art. 124 ust. 4 u.g.n. mają charakter ściśle odszkodowawczy, ograniczony do szkód powstałych na nieruchomości oraz zmniejszenia się wartości nieruchomości ${ }^{39}$.

W sprawach dotyczących realizacji inwestycji drogowych w trybie przepisów specustawy drogowej analogiczny pogląd co do konieczności istnienia takiego ścisłego, skonkretyzowanego przebiegu drogi w planie nie jest szczególnie akcentowany. Wynika to najprawdopodobniej z faktu, że co do zasady jako oczywiste jest przyjęte, że zgodność z planem miejscowym w zakresie przebiegu drogi publicznej zachodzi właśnie wtedy, gdy jest ona zlokalizowana precyzyjnie na terenie przeznaczonym na taki cel, a nie może wynikać z zapisów ogólnych planu. Wydając natomiast decyzję o realizacji inwestycji drogowej, w przypadku braku planu miejscowego organ nie jest związany zapisami odrębnej decyzji lokalizacyjnej, ponieważ to właśnie ta decyzja, wydana na podstawie przepisów ustawy o inwestycjach drogowych, zawiera rozstrzygnięcie w kwestii lokalizacji drogi. Organ rozstrzygający tę sprawę ocenia jedynie prawną dopuszczalność przebiegu drogi publicznej w miejscu przewidzianym przez wnioskodawcę. Prowadzi to do wniosku, że treść wniosku zasadniczo przesądza, jakie grunty podlegać będą wywłaszczeniu ${ }^{40}$.

Zastanowienia wymaga również, czy kontrolując legalność rozwiązań w zakresie lokalizacji drogi publicznej, nie można wykorzystać mechanizmu kontroli proporcjonalności, stosowanego przez sądy administracyjne przy badaniu zgodności z prawem rozwiązań dotyczących ograniczenia prawa własności w miejscowych planach zagospodarowania przestrzennego. Trzeba zauważyć, że ingerencja w sferę prawa własności, charakteryzująca rozstrzygnięcie w sprawie zgody na realizację drogi publicznej, pozostawać musi w racjonalnej i odpowiedniej proporcji do wskazanych wyżej celów, dla osiągnięcia których ustanawia się okre-

39 Wyrok WSA w Lublinie z dnia 12 lutego 2019 r., II SA/Lu 810/18, LEX nr 2634341.

${ }^{40} \mathrm{M}$. Wolanin, Ustawa o szczególnych zasadach przygotowania i realizacji inwestycji $w$ zakresie dróg publicznych. Komentarz, Warszawa 2010, s. 70, 74. 
ślone ograniczenia. Prowadzi to do wniosku, że uzasadnienie tej decyzji powinno zawierać argumentację, która umożliwia przekonanie jej adresatów (zwłaszcza tych, którym przymusowo odebrano prawo własności), że wnioskodawca dołożył należytej staranności, wytyczając przyjęty wariant przebiegu drogi, w tym rozważył inne warianty zrealizowania tego zamierzenia w ramach przyjętej koncepcji, albo że przyjęte $\mathrm{w}$ tym zakresie rozwiązanie, mimo konieczności dokonania ingerencji w sferę prawa własności, jest jedynym możliwym w danych warunkach. Nie powinno przecież budzić wątpliwości, że skoro w tym zakresie wnioskodawca działa w ramach pewnej „uznaniowości”, to tym bardziej spoczywa na nim ciężar wykazania tych kwestii po to właśnie, aby uniknąć zarzutu arbitralności ustalonego przezeń przebiegu inwestycji.

$\mathrm{Z}$ tego powodu jako zbyt powierzchowne oceniam przywołane wyżej stanowisko orzecznictwa wskazujące na brak możliwości kwestionowania przebiegu drogi publicznej ustalonego w decyzji o zezwoleniu na jej realizację. Takiego ograniczenia zakresu sądowoadministracyjnej kontroli nie uzasadniają przywołane wyżej pragmatyczne wartości, w tym sprawność realizacji inwestycji drogowych. Mechanizm kontroli sądowej, ale też kontroli instancyjnej w ramach postępowania administracyjnego, powinien opierać się na ocenie zachowania wymogów wynikających $\mathrm{z}$ zasady ochrony prawa własności i nakazu proporcjonalnej ingerencji w to prawo. Zachowanie „skutecznego" instrumentu prawnego służącego realizacji inwestycji publicznych nie może oznaczać rezygnacji z oceny, czy ingerencja władzy publicznej w prawo własności nieruchomości uwzględnia proporcjonalnie wyważony interes publiczny $\mathrm{z}$ interesem podmiotów, którym to prawo dotychczas przysługiwało. Sąd administracyjny nie może uchylać się od skontrolowania, czy organ administracji wnikliwie i wszechstronnie wyważył interes publiczny i interes indywidualny, a także czy w tym kontekście należycie uzasadnił prawidłowość przyjętego przebiegu drogi. Taka ocena gwarantuje bowiem wyeliminowanie sytuacji, w której organ nadużyłby przysługującego mu władztwa administracyjnego.

Ochrona własności musi być harmonizowana $\mathrm{z}$ wymogami uwzględniania ochrony interesu publicznego. Polem dla urzeczywistnienia tego procesu powinna być - na gruncie stosowania omawianej ustawy - kwestia kształtowania przebiegu drogi publicznej. Powtórzyć należy, że niekiedy ustalenie lokalizacji drogi publicznej w ramach zezwolenia na jej realizację jest ściśle uwarunkowane wymogami ładu przestrzennego (w tym zapisami miejscowego planu zagospodarowania przestrzennego), a także koniecznością uwzględnienia dotychczasowego przebiegu tej drogi. Ważne jest jednak, by mieć świadomość, że nawet te warunki, silnie uzależnione otoczeniem planowanej inwestycji, pozostawiają wnioskodawcy pewien margines swobody dla optymalnego wyboru lokalizacji drogi. W tej sferze szczególnego znaczenia nabiera potrzeba wyważenia interesu publicznego oraz słusznego interesu obywatela, co jest wymogiem określonym w art. 7 k.p.a., a zarazem stanowi istotny element zasady pogłębiania zaufania (art. 8 k.p.a.). 
Wskazać należy, że niezwykle ważna dla oceny konstytucyjności ograniczenia prawa własności dokonywanego na podstawie przepisów ustawy o inwestycjach drogowych jest odpowiedź na pytanie, czy w tych sprawach zasadą jest jak najszersza ochrona prawa własności, a co za tym idzie wszelkie wyjątki od tej zasady należy interpretować ścieśniająco, czy też przeciwnie - jako regułę należy traktować ograniczenie prawa własności, co ma służyć realizacji interesu publicznego. W literaturze wskazuje się - jako bardziej odpowiadający modelowi gospodarki rynkowej - pogląd, zgodnie z którym podstawowe znaczenie przypisać należy wolności jednostki w korzystaniu z własności, z zastrzeżeniem, że wolność ta jest obwarowana całym szeregiem ograniczeń wynikających z potrzeby uwzględnienia wymagań interesu publicznego, których istota wyraża się w przyjętej w doktrynie i orzecznictwie niemieckich sądów koncepcji społecznej funkcji własności (społecznym związaniu własności). Inaczej mówiąc, obie te wartości: wolność właściciela i społeczna funkcja własności - pozostają w ścisłym związku ${ }^{41}$.

Wydaje się jednak, że zarówno orzecznictwo Trybunału Konstytucyjnego, jak i sądów administracyjnych przychyla się, gdy chodzi o ocenę mechanizmu wywłaszczenia nieruchomości, wynikającego z istoty rozstrzygnięcia zawartego w decyzji o zezwoleniu na realizację inwestycji drogowej, do akceptacji prymatu koncepcji społecznego związania własności nad wolnością właściciela. Świadczy o tym z jednej strony uznanie za mieszczące się w konstytucyjnej formule proporcjonalności rozwiązań ekspropriacyjnych zawartych w tej ustawie. $Z$ drugiej strony potwierdza to powszechnie przyjęte w orzecznictwie sądów administracyjnych stanowisko o braku możliwości dokonywania oceny przyjętych przez wnioskodawcę rozwiązań dotyczących przebiegu drogi publicznej, poza oceną ich zgodności z zapisami planu miejscowego. Stanowisko to może prowadzić do nieakceptowalnych z punktu widzenia zasady sprawiedliwości społecznej rozwiązań. Przykładowo skoro nie ma ustawowo skonstruowanego wymogu lokalizowania takich dróg na terenie nieruchomości stanowiących własność jednostek samorządu terytorialnego bądź Skarbu Państwa, to łatwo przyjąć, że nie ma również $\mathrm{w}$ istocie podstaw prawnych, aby zakwestionować legalność działania wnioskodawcy, który w przypadku nieuchwalenia na danym terenie planu miejscowego zaplanowałby przebieg przyszłej drogi publicznej wyłącznie na gruntach stanowiących własność prywatną pomimo istnienia alternatywnej możliwości przeprowadzenia tej drogi na gruncie należącym do tych jednostek samorządowych lub Skarbu Państwa. A jak należałoby ocenić działanie wnioskodawcy w hipotetycznej sytuacji, gdy część stron postępowania zgodnie podnosiłaby zarzut, niekwe-

${ }^{41}$ J. Parchomiuk, Publicznoprawne ograniczenia własności we współczesnym demokratycznym państwie prawa, [w:] Nowe kierunki działań administracji publicznej w Polsce i Unii Europejskiej, red. P. Chmielnicki, A. Dybała, Warszawa 2009, s. 341-342. 
stionowany przez pozostałe strony, że projektowana droga przebiega wyłącznie bądź w znacznej części przez ich nieruchomości, mimo że w bezpośrednim sąsiedztwie znajdują się nieruchomości stanowiące własność pracowników urzędu gminy, na których również jest dopuszczalne wybudowanie tej drogi? Czy w tym ostatnim przypadku można z góry wykluczyć dopuszczalność dokonania oceny? Czy organ, wydając zaskarżony akt, nie dopuścił się nadużycia władztwa administracyjnego? Niewątpliwie wyłączenie możliwości skutecznego podnoszenia tego rodzaju wątpliwości w postępowaniu administracyjnym oraz w postępowaniu przed sądem administracyjnym stanowiłoby naruszenie konstytucyjnie chronionego prawa do sądu.

Wskazana wyżej koncepcja ograniczonej kontroli decyzji o zezwoleniu na realizację inwestycji drogowej rodzi też wątpliwości co do zgodności z konstytucyjną zasadą ochrony własności. Koncepcja ta, wywodzona z wyników wykładni funkcjonalnej i systemowej przepisów specustawy drogowej, prowadzić może do pozostawienia w obrocie prawnym rozstrzygnięć, które prowadzą do nieproporcjonalnego ograniczenia własności. Wynika to ze specyficznych dla tej procedury rozwiązań prawnych. Ustawa ułatwia bowiem utrwalenie praktyki nagminnego zaopatrywania omawianej decyzji w rygor natychmiastowej wykonalności, co wynika z opisanej wyżej, bardzo pojemnej przesłanki stosowania tej instytucji. Jednocześnie z nadaniem tego rygoru ustawa wiąże wprowadzony bez wyjątków zakaz uchylania oraz stwierdzania nieważności tych decyzji w okolicznościach określonych w art. 31 . Przy założeniu, że skarga na ostateczną decyzję w tym przedmiocie jest rozpatrywana po upływie 14 dni od dnia rozpoczęcia robót budowlanych, co jest regułą, jeśli zważyć konieczność uprzedniego wyczerpania kontroli instancyjnej, wymagany czas na przygotowanie i złożenie skargi do wojewódzkiego sądu administracyjnego oraz czas potrzebny na wyznaczenie rozprawy, a zarazem na „rozpoczęcie robót budowlanych", ma miejsce w razie podjęcia nieskomplikowanych (z uwagi na skalę inwestycji) czynności poprzedzających zasadnicze prace budowlane, jak wytyczenie geodezyjne obiektu w terenie, należy w istocie przyjąć, że ustawodawca praktycznie wyłączył możliwość zakwestionowania przez sąd rozwiązań ekspropriacyjnych przyjętych przez wnioskodawcę ${ }^{42}$. Stwierdzenie wydania takiej decyzji z naruszeniem prawa pozostawia zaś zainteresowanemu, w celu ewentualnego zrekompensowania szkody, znacznie trudniejszą, bo bardziej wymagającą z uwagi na obowiązywanie zasady skargowości, i zarazem bardziej kosztowną drogę odszkodowawczą w postępowaniu cywilnym.

Przyjęcie pozytywistycznego nastawienia niesłychanie ułatwia uniknięcie opisanych wyżej dylematów wynikających ze stosowania przepisów ustawy. W konsekwencji uznania za trafną szerokiej koncepcji prawnej „nieomylności”

${ }^{42} \mathrm{Na}$ okoliczności te zwrócono uwagę także we wspomnianym zdaniu odrębnym sędziego W. Hermelińskiego do wyroku TK z dnia 16 października 2012 r. (K 4/10). 
wnioskodawcy - zarządcy drogi publicznej - w postępowaniu o wydanie omawianej decyzji łatwo jest odkodować z przepisów ustawy takie normy prawne, które umożliwiają afirmację zamysłu inwestycyjnego przyjętego przez inicjatora postępowania. Wychodząc $z$ tej perspektywy poznania i stosowania prawa, nie można mówić w omawianym przypadku o naruszeniu zasady ochrony zaufania obywatela do państwa i jego organów, skoro wymogi sprawiedliwości formalnej (proceduralnej) zostały spełnione.

W mojej ocenie przypisanie powyższej zasadzie treści odwołującej się także do wymagań sprawiedliwości materialnej pozwala na otwarcie kryterium legalności o wartości sprzeciwiającej się instrumentalnemu traktowaniu prawa własności jako środka, który zależnie od woli inwestora drogi publicznej może być poświęcony dla realizacji celu, jakim jest budowa tego obiektu. W przeciwnym razie zasada praworządności mieć będzie we wskazanym procesie inwestycyjnym charakter jedynie ornamentacyjny. Władza publiczna będzie działać wówczas zgodnie z prawem ustanowionym prawidłowo formalnie, ale już nie takim, które gwarantuje też równość sytuacji prawnej wszystkich adresatów norm o tych samych cechach istotnych, poszanowanie zasady prawdy materialnej oraz ochronę podstawowych praw i wolności człowieka.

Być może również na takich założeniach, choć nieujawnionych w treści uzasadnień wyroków, opiera się argumentacja podnoszona przez niektóre składy orzekające sądów administracyjnych, niezwiązane - z mocy art. 269 § 1 p.p.s.a. - stanowiskiem zawartym w powołanym postanowieniu składu poszerzonego NSA z dnia 17 grudnia 2014 r. (II OPS 2/14). Z jednej strony uznają one, że organ administracji, a co za tym idzie także sąd administracyjny, nie może oceniać racjonalności czy słuszności przyjętych we wniosku rozwiązań projektowych, ponieważ postępowanie w sprawie zezwolenia na realizację inwestycji drogowej toczy się na wniosek zarządcy drogi, którym to wnioskiem organ jest związany. Z drugiej strony jednak wskazują, że rolą organów administracji nie może być mechaniczne zatwierdzanie rozwiązań proponowanych przez inwestora drogi publicznej, jedynie po przeprowadzeniu formalnej oceny kompletności złożonej przezeń dokumentacji. Dlatego za dopuszczalną uznają weryfikację zasadności jego żądania w zakresie ewentualnego istnienia rozwiązania alternatywnego zapewniającego możliwość realizacji tego samego celu publicznego, przy ograniczeniu stopnia ingerencji w prawo własności osób trzecich, a także ocenę niezbędności realizacji celu tej inwestycji jako przesłanki ingerencji w prawo własności nieruchomości. Zarazem sądy zastrzegają, że ta weryfikacja nie może mieć na celu samej kontroli zasadności poszczególnych rozwiązań wskazanych we wniosku, ale służy zbadaniu niezbędności inwestycji do realizacji ogólnego celu przedsięwzięcia drogowego ${ }^{43}$.

${ }^{43}$ Zob. wyrok NSA z dnia 3 września 2014 r., II OSK 1730/14, LEX nr 1664490. Wyrok ten jest jednak zasadniczo powoływany przez sądy administracyjne jako ilustrujący przeciwną w istocie 


\section{PODSUMOWANIE}

Wskazać trzeba, że celem etosu prawnego jest ukształtowanie i utrwalenie przez przepisy prawa porządku sprawiedliwego, ludzkiego i odpowiadającego godności człowieka. Dlatego oddziaływanie etosu prawnego nie może wyrażać się w wykonywaniu przymusu, lecz w poczuciu obowiązku postępowania zgodnego z prawem. W konsekwencji ustawodawca nie jest uprawniony do stanowienia norm prawnych o dowolnej treści, lecz ma obowiązek kształtować je w zgodzie ze słusznością i prawością. Legitymacja do działalności prawodawczej pochodzi ze źródła wyższego. Źródłem tym jest hierarchia wartości przyjęta w grupie społecznej, która wiąże człowieka w sumieniu, zobowiązując go do przestrzegania normy prawnej ${ }^{44}$.

Podejmowanie czynności na rzecz dobra wspólnego musi być refleksem słuszności i prawości, gdyż bez tego aksjologicznego fundamentu działania administracji prowadzić mogą do podporządkowania dobra jednostki celom społecznym w sposób jedynie pozornie praworządny. Konsekwencją lekceważenia takiego obowiązku może być finalnie całkowity rozpad demokratycznego państwa prawa. Zmiana układu tak istotnych dóbr prawnie chronionych przynosi bowiem, co pokazuje historia, powrót do egzystencji siły, która prowadzi do zachwiania równowagi pomiędzy dwoma możliwymi elementami porządku prawnego - etyką i siłą, na rzecz siły ${ }^{45}$.

W strefie nieuzasadnionego komfortu pozostawałoby przyjęcie bez zastrzeżeń przekonania, że rozwiązania „siłowe”, których odbicie odnaleźć można $\mathrm{w}$ przepisach ustaw regulujących inwestycje infrastrukturalne, mają charakter zupełnie wyjątkowy i powinny być traktowane jedynie jako rozwiązania przejściowe, epizodyczne. Akceptację takiej postawy utrudniają doświadczenia związane ze stosowaniem ustawy o realizacji inwestycji drogowych, która - mając na względzie jej obecne brzmienie - funkcjonować będzie w polskim porządku prawnym ponad 20 lat, choć nie da się wykluczyć, że i ten termin zostanie w przyszłości wydłużony, skoro dotychczas czyniono to kilkakrotnie ${ }^{46}$.

tezę (również eksponowaną w tym wyroku) o prawnym związaniu organu i sądu treścią rozwiązań przyjętych we wniosku o wydanie omawianej decyzji. Zob. np. wyroki NSA z dnia: 16 kwietnia 2019 r., II OSK 25/19, LEX nr 2678803; 27 lutego 2019 r., II OSK 3430/18, LEX nr 2646601.

${ }^{44}$ A. Kość, Podstawy filozofii prawa, Lublin 2005, s. 235-236.

${ }^{45}$ Uwagi takie odnosił C. Martyniak do rodzącego się w latach 30. XX w. państwa nazistowskiego. Zob. C. Martyniak, Problem filozofii prawa. Filozofia prawa, jej przedmiot, metoda i podziat, Lublin 1949, s. 2, powołuję za: M. Łuszczyńska, Filozofia prawa Czesława Martyniaka, Lublin 2008, s. 258.

${ }^{46}$ Pierwotnie ustawa miała obowiązywać do 31 grudnia 2007 r., następnie do 31 grudnia 2013 r. oraz do 31 grudnia 2020 r. Ostatnio - na mocy nowelizacji dokonanej ustawą z dnia 5 sierpnia 2015 r. o zmianie ustawy o szczególnych zasadach przygotowania i realizacji inwestycji w zakresie dróg publicznych oraz niektórych innych ustaw (Dz.U. 2015, poz. 1590) - termin ten wydłużono do 31 grudnia 2023 r. 


\section{BIBLIOGRAFIA}

\section{LITERATURA}

Jan Paweł II, Veritatis Splendor. Tekst i komentarze, Lublin 1999.

Kiereś H., Agatologia czy aksjologia?, [w:] Spór o dobro, red. A. Maryniarczyk, K. Stępień, P. Gondek, Lublin 2012.

Komierzyńska E., Zdyb M., Klauzula interesu publicznego $w$ działaniach administracji publicznej, „Annales UMCS sectio G(Ius)”2016, nr 2, DOI: http://dx.doi.org/10.17951/g.2016.63.2.161.

Kość A., Podstawy filozofii prawa, Lublin 2005.

Kotulski M., Problemy w ksztaltowaniu przestrzeni w procesie planowania i zagospodarowania przestrzennego, [w:] Przestrzeń i nieruchomości jako przedmiot prawa administracyjnego. Publiczne prawo rzeczowe, red. I. Niżnik-Dobosz, Warszawa 2012.

Łuszczyńska M., Filozofia prawa Czesława Martyniaka, Lublin 2008.

Martyniak C., Problem filozofii prawa. Filozofia prawa, jej przedmiot, metoda i podziat, Lublin 1949.

Maryniarczyk A., Dobro bytu, [w:] S. Thomae Aquinatis. Quaestiones disputatae de bono, de appetitu boni et voluntate - Dysputy problemowe o dobru, o pożadaniu dobra $i$ o woli, red. A. Maryniarczyk, Lublin 2003.

Matusik G., [w:] G. Bieniek, M. Gdesz, S. Kalus, G. Matusik, E. Mzyk, Ustawa o gospodarce nieruchomościami. Komentarz, Warszawa 2012.

Parchomiuk J., Publicznoprawne ograniczenia własności we wspótczesnym demokratycznym państwie prawa, [w:] Nowe kierunki działań administracji publicznej w Polsce $i$ Unii Europejskiej, red. P. Chmielnicki, A. Dybała, Warszawa 2009.

Parchomiuk J., Uproszczone procedury realizacji publicznych inwestycji infrastrukturalnych a ochrona praw jednostki, [w:] Przestrzeń i nieruchomości jako przedmiot prawa administracyjnego. Publiczne prawo rzeczowe, red. I. Niżnik-Dobosz, Warszawa 2012.

Wolanin M., Ustawa o szczególnych zasadach przygotowania i realizacji inwestycji w zakresie dróg publicznych. Komentarz, Warszawa 2010.

Zdyb M., Dylematy ładu prawnego w kontekście inflacji i niektórych innych niedoskonałości prawa administracyjnego, [w:] Prawo administracyjne dziś i jutro, red. J. Jagielski, M. Wierzbowski, Warszawa 2018.

Zdyb M., Konstytucyjne podstawy administracyjnoprawnych ograniczeń prawa własności jako podstawowego prawa rzeczowego (i ograniczonych praw rzeczowych), [w:] System Prawa Administracyjnego, t. 7: Prawo administracyjne materialne, red. R. Hauser, A. Wróbel, Z. Niewiadomski, Warszawa 2017.

Zimmermann J., Prawo administracyjne, Warszawa 2014.

\section{AKTy PRAWNe}

Konstytucja Rzeczypospolitej Polskiej z dnia 2 kwietnia 1997 r. (Dz.U. 1997, nr 78, poz. 483 ze zm.). Ustawa z dnia 14 czerwca 1960 r. - Kodeks postępowania administracyjnego (Dz.U. 2018, poz. 2096 ze zm.).

Ustawa z dnia 21 sierpnia 1997 r. o gospodarce nieruchomościami (Dz.U. 2014, poz. 518 ze zm., Dz.U. 2018, poz. 2204 ze zm.).

Ustawa z dnia 30 sierpnia 2002 r. - Prawo o postępowaniu przed sądami administracyjnymi (Dz.U. 2018, poz. 1302 ze zm.).

Ustawa z dnia 28 marca 2003 r. o transporcie kolejowym (Dz.U. 2019, poz. 710).

Ustawa z dnia 10 kwietnia 2003 r. o szczególnych zasadach przygotowania i realizacji inwestycji w zakresie dróg publicznych (Dz.U. 2018, poz. 1474 ze zm.).

Ustawa z dnia 16 kwietnia 2004 r. o ochronie przyrody (Dz.U. 2018, poz. 1614).

Ustawa z dnia 16 grudnia 2005 r. o zmianie ustawy o transporcie kolejowym oraz o zmianie innych ustaw (Dz.U. 2006, nr 12, poz. 63). 
Ustawa z dnia 18 października 2006 r. o zmianie ustawy o szczególnych zasadach przygotowania i realizacji inwestycji w zakresie dróg krajowych oraz o zmianie niektórych innych ustaw (Dz.U. nr 220, poz. 1601 ze zm.).

Ustawa z dnia 7 września 2007 r. o przygotowaniu finałowego turnieju Mistrzostw Europy w Piłce Nożnej UEFA EURO 2012 (Dz.U. 2017, poz. 1372).

Ustawa z dnia 12 lutego 2009 r. o szczególnych zasadach przygotowania i realizacji inwestycji w zakresie lotnisk użytku publicznego (Dz.U. 2018, poz. 1380 ze zm.).

Ustawa z dnia 24 kwietnia 2009 r. o inwestycjach w zakresie terminalu regazyfikacyjnego skroplonego gazu ziemnego w Świnoujściu (Dz.U. 2017, poz. 2302 ze zm.).

Ustawa z dnia 7 maja 2010 r. o wspieraniu rozwoju usług i sieci telekomunikacyjnych (Dz.U. 2017, poz. 2062 ze zm.).

Ustawa z dnia 24 czerwca 2010 r. o szczególnych rozwiązaniach związanych z usuwaniem skutków powodzi z 2010 r. (Dz.U. nr 123, poz. 835 ze zm.).

Ustawa z dnia 8 lipca 2010 r. o szczególnych zasadach przygotowania do realizacji inwestycji w zakresie budowli przeciwpowodziowych (Dz.U. 2019, poz. 933 ze zm.).

Ustawa z dnia 29 czerwca 2011 r. o przygotowaniu i realizacji inwestycji w zakresie obiektów energetyki jądrowej oraz inwestycji towarzyszących (Dz.U. 2018, poz. 1537).

Ustawa z dnia 16 września 2011 r. o szczególnych rozwiązaniach związanych z usuwaniem skutków powodzi (Dz.U. 2018, poz. 1473 ze zm.).

Ustawa z dnia 24 lipca 2015 r. o przygotowaniu i realizacji strategicznych inwestycji w zakresie sieci przesyłowych (Dz.U. 2018, poz. 404 ze zm.).

Ustawa z dnia 5 sierpnia 2015 r. o zmianie ustawy o szczególnych zasadach przygotowania i realizacji inwestycji w zakresie dróg publicznych oraz niektórych innych ustaw (Dz.U. 2015, poz. 1590).

Ustawa z dnia 24 lutego 2017 r. o inwestycjach w zakresie budowy drogi wodnej łączącej Zalew Wiślany z Zatoką Gdańską (Dz.U. 2019, poz. 1073).

Ustawa z dnia 7 kwietnia 2017 r. o inwestycjach w zakresie budowy lub przebudowy toru wodnego Świnoujście-Szczecin do głębokości 12,5 metra (Dz.U. 2017, poz. 990).

Ustawa z dnia 20 lipca 2017 r. - Prawo wodne (Dz.U. 2018, poz. 2268 ze zm.).

Ustawa z dnia 10 maja 2018 r. o Centralnym Porcie Komunikacyjnym (Dz.U. 2018, poz. 1089 ze zm.).

Ustawa z dnia 10 maja 2018 r. o wspieraniu nowych inwestycji (Dz.U. 2018, poz. 1162 ze zm.).

Ustawa z dnia 5 lipca 2018 r. o ułatwieniach w przygotowaniu i realizacji inwestycji mieszkaniowych oraz inwestycji towarzyszących (Dz.U. 2018, poz. 1496 ze zm.).

Ustawa z dnia 22 lutego 2019 r. o przygotowaniu i realizacji strategicznych inwestycji w sektorze naftowym (Dz.U. 2019, poz. 630 ze zm.).

\section{Orzecznictwo}

Postanowienie NSA z dnia 17 grudnia 2014 r., II OPS 2/14, LEX nr 1566894.

Wyrok NSA z dnia 25 lutego 2014 r., II GSK 1924/12, LEX nr 1495127.

Wyrok NSA z dnia 3 września 2014 r., II OSK 1730/14, LEX nr 1664490.

Wyrok NSA z dnia 23 października 2014 r., I OSK 537/13, LEX nr 1591039.

Wyrok NSA z dnia 27 września 2016 r., II OSK 1887/19, LEX nr 2167520.

Wyrok NSA z dnia 2 lutego 2017 r., I OSK 1036/15, LEX nr 2253603.

Wyrok NSA z dnia 2 marca 2017 r., I OSK 1196/15, LEX nr 2348986.

Wyrok NSA z dnia 21 marca 2017 r., I OSK 1704/15, LEX nr 2289926.

Wyrok NSA z dnia 7 lipca 2017 r., I OSK 2668/15, LEX nr 2347631.

Wyrok NSA z dnia 27 lutego 2019 r., II OSK 3430/18, LEX nr 2646601.

Wyrok NSA z dnia 16 kwietnia 2019 r., II OSK 25/19, LEX nr 2678803.

Wyrok TK z dnia 16 października 2012 r., K 4/10, OTK-A 2012, nr 9, poz. 106.

Wyrok WSA w Lublinie z dnia 12 lutego 2019 r., II SA/Lu 810/18, LEX nr 2634341. 


\section{SUMMARY}

The jurisprudence of administrative courts maintains that in proceedings regarding the authorization of a road investment, in the light of the provisions of the Act of 10 April 2003 on Special Rules of Preparation and Realization of Investments in Public Roads, administrative bodies can not judge necessity and purposefulness of solutions regarding the location of the road, according to the investor's application. This is because this procedure is pending at the request of the road administrator and the administrative body is bound by this request. Consequently, the content of the application determines which land will be subject to expropriation. However, this position raises many doubts in the context of the constitutional principles of protection of property and proportionality. It may lead to the imbalance between the need to realize the public goal, which is the building of the public road and the obligation to take into account the legitimate interest of the expropriated property's owner.

Keywords: infrastructure investments; public roads; location of the public roads; principle of proportionality; protection of property

\section{STRESZCZENIE}

W orzecznictwie sądów administracyjnych utrwalone jest stanowisko, że w postępowaniu w sprawie zezwolenia na realizację danej inwestycji drogowej, w trybie przepisów ustawy z dnia 10 kwietnia 2003 r. o szczególnych zasadach przygotowania i realizacji inwestycji w zakresie dróg publicznych, organy administracji nie mogą oceniać niezbędności i celowości rozwiązań dotyczących lokalizacji drogi, przyjętych we wniosku, gdyż postępowanie to toczy się na wniosek zarządcy drogi, którym to wnioskiem organ administracji jest związany. W konsekwencji to treść wniosku przesądza, jakie grunty podlegać będą wywłaszczeniu. Stanowisko to budzi jednak wiele wątpliwości w kontekście konstytucyjnych zasad ochrony własności i proporcjonalności, gdyż może prowadzić do zachwiania równowagi pomiędzy koniecznością realizacji celu publicznego, jakim jest budowa drogi publicznej, a obowiązkiem uwzględnienia słusznego interesu właściciela nieruchomości wywłaszczanej.

Słowa kluczowe: inwestycje infrastrukturalne; drogi publiczne; lokalizacja dróg publicznych; zasada proporcjonalności; ochrona własności 